\title{
Rancang Bangun Game Edukasi Pemilihan Gubernur Jateng Berbasis Android Dengan Model ADDIE
}

\author{
Aris Tri Jaka Harjanta ${ }^{1}$, Bambang Agus Herlambang ${ }^{2}$ \\ 1, Program Studi Informatika/Universitas PGRI Semarang \\ 2. Jl. Sidodadi Timur No. 24 Semarang/e-mail: aristrijaka@gmail.com
}

\section{ARTICLE INFO}

Article history:

Received 8 Agustus 2018

Received in revised form 10 Agustus 2018

Accepted 14 September 2018

Available online 17 Agustus 2018

\section{ABSTRACT}

Dalam sebuah pembelajaran, media pembelajaran memberikan sebuah peran yang sangat dominan dalam menyampaikan sebuah materi sesuai dengan bahan ajar. Penggunaan ponsel pintar atau smartphone dalam kehidupan sehari - hari sudah semakin umum dan sebagian besar ponsel pintar menggunakan sistem operasi android, serta mempunyai bentuk dan ukuran yang sudah sangat bervariatif namun mayoritas menggunakan layar sentuh dalam pengoperasiannya. Pada saat sekarang Komisi Pemilihan Umum (KPU) provinsi Jawa tengah sedang dalam proses sosialisasi untuk memberikan pengetahuan kepada masyarakat terkait informasi pemilihan kepala daerah (gubernur) Jateng periode 2018 - 2023. Dengan ini maka dibuat sistem pembelajaran dan pemberitahuan kepada masyarakat dalam bentuk game yang dikemas dalam permainan berbasis android untuk memberikan edukasi yang menyenangkan dan menarik.

Keywords: game, edukasi, android, pilgub, aplikasi

\section{Introduction}

Perkembangan teknologi saat ini telah menunjukkan perubahan yang sangat signifikan di semua lini kehidupan masyarakat dan tak terkecuali dalam hal pembelajaran serta sosialisasi, dimana pemberian pengetahuan dapat dilakukan dengan media informasi yang menggunakan teknologi informasi komunikasi yang sangat beragam. Sebuah permainan atau game juga merupakan salah satu media yang dapat dan mampu digunakan untuk memberikan sebuah pembelajaran kepada para penggunanya.

Saat ini Komisi Pemilihan Umum (KPU) sedang memberikan sosialisasi terkait dengan pemilihan gubernur Jawa Tengah tahun 2018, dengan mengambangkan sebuah game edukasi diharapkan dapat memberikan kontribusi dalam pembelajaran ke masyarakat dengan cara yang relatif lebih nyaman dan dengan tanpa paksaan maka secara tidak sadar telah diberikan informasi baik dengan media visual maupun audio dalam aplikasi game berbasis android. Aplikasi berbasis android masih menjadi pilihan karena saat ini ponsel pintar android hampir dimiliki oleh berbagai lapisan masyarakat.

Aplikasi permainan dalam bentuk pertanyaan yang disajikan secara acak akan memberikan pengalaman yang beragam bagi penggunanya sehingga menghindarkan dari rasa bosan dan dapat dimainkan secara berulang - ulang dan didapatkan kombinasi pertanyaan yang akan berubah - rubah ditambah dengan penyajian dalam bentuk modul roda berputar akan 
memberikan penampakan visualisasi yang segar dan atraktif. Memberikan jawaban juga merupakan bagian yang memberikan pengalaman tersendiri juga kepada pengguna dalam hal ini metode pengisian jawaban dibuat dengan bentuk modul yang mengadopsi sistem teka teki silang dengan menyajikan kotak- kotak kosong sejumlah huruf yang dapat dimasukkan secara manual oleh pengguna, disertai dengan bantuan jawaban yang berupa satu huruf di salah satu kotak yang tersedia.

\section{Research Method}

Pada penelitian ini yang merupakan sebuah sistem Digital Game Base Learning (DGSL) maka metode penelitian yang peneliti gunakan adalah dengan model yaitu Analisis (Analyzing), Desain (Design), Pengembangan (Development), Implementasi (Implementation), dan Evaluasi (Evaluate) atau lebih sering disingkat dengan model ADDIE. Model ini memiliki beberapa tahapan yang sesuai dengan namanya yaitu (1) analisis, (2) Desain, (3) pengembangan, (4) Implementasi dan diakhiri dengan tahap (5) evaluasi, namun model ADDIE memiliki fokus atau penekanan pada iterasi dan refleksi. Sehingga perbaikan secara terus menerus dapat dilakukan yang berfokus dari umpan balik[1][2].

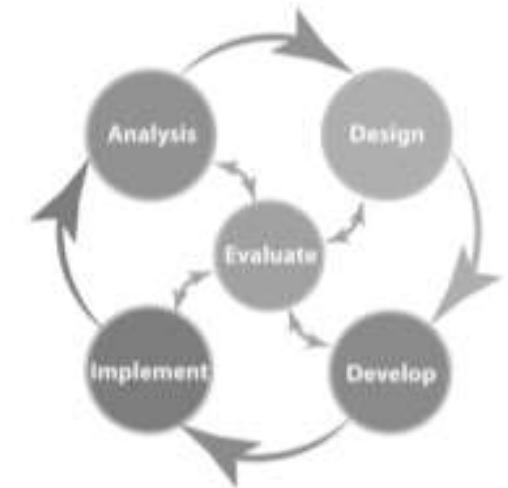

Gambar 1. ADDIE model

\subsection{Tahap Analisis (Analyzing)}

Tahapan ini adalah sebuah proses mendefinisikan materi atau apa saja yang akan dipelajari oleh calon pengguna sistem atau game ini nantinya. Cara yang dilakukan pada tahapan ini adalah dengan melakukan analisis kebutuhan (needs assessment) kemudian mengidentifikasi masalah dan kebutuhan, kemudian melakukan analisa tugas (task analysis). Dan pada proses atau tahapan ini akan dihasilkan hasil analisa yang meliputi permasahan yang dihadapi, kebutuhan yang diperlukan untuk desain sistem, serta apa saja tugas yang mampu diselesaikan pada DGBL yang akan di buat nantinya[3].

\subsection{Tahap Desain (Design)}

Tahapan desain adalah proses yang dilakukan mendahului sebelum dilakukan pengembangan sistem. Pada tahapan ini dilakukan dengan penentuan cara atau strategi pembelajaran yang nantinya akan digunakan, dan kemudian model pembelajaran yang akan diterapkan pada aplikasi ini. Sehingga hasil akhir dati tahapan desain ini adalah rancangan atau desain yang mampu menjawab permasalahan dari proses analisis sebelumnya dan memiliki rencana terkait dengan pengalama belajar yang akan diperoleh pengguna aplikasi kedepan[3].

\subsection{Tahap Pengembangan (Development)}

Tahapan pengembangan adalah tahapan untuk mewujudkan secara benar dari tahapan desain yang telah di buat sebelumnya sesuai dengan kaidah - kaidah atau aturan sebuah pencangan perangkat lunak (software). Pada tahapan ini meliputi penentuan dan pemilihan metode pengembangan sistem, serta pemilihan tools dan aplikasi pendukung yang akan digunakan dalam pembuatan sistem atau aplikasi ini nantinya. 
Hasil dari tahapan ini adalah rancangan aplikasi yang sesuai aturan pengembangan sistem informasi perangakat lunak yang nantinya akan dapat di implenentasikan pada tahapan ADDIE selanjutnya[4].

\subsection{Tahap Implementasi (Implementation)}

Tahapan ini adalah tahapan mengimplenetasikan semua desain atau perancangan sistem informasi yang telah dibuat pada tahapan sebelumya kedalam sebuah aplikasi dengan menggunakan tools yang telah di pilih pada tahapan sebelumnya[5]. Jadi dengan kata lain tahapn ini adalah tahap membuat apliasi menjadi bentuk aplikasi game yang sesungguhnya, jadi hasil akhir dari tahapan ini alaha sebuah aplikasi game DGBL yang telah siap digunakan namun masih ada tahapan lagi sebelum dapat di gunakan secara umum[6].

\subsection{Tahap Evaluasi (Evaluation)}

Tahapan ini adalah tahapan akhir dari model ADDIE. Evaluasi merupakan disini dilakukan untuk mengevaluasi apakah aplikasi yang dibangun sudah sesuai atau belum dengan yang diharapkan[7]. Pada tahapan ini aplikasi di ujicoba untuk mencari kesalahan (bug) secara sistem atau teknik yang mungkin dapat terjadi. Hasil dari tahapan ini adalah laporan hasil pengujian sistem[8].

\section{Results and Analysis}

\subsection{Analisis (Analyzing)}

dalam rangka mengembangkan game ini beberapa hal yang dapat diperoleh diataranya sebgai berikut :

a. kebutuhan sistem

dalam game ini diharapkan membuat sebuah game yang mampu berinteraksi dengan pengguna dan memberikan pengalaman serta pengetahuan terhadap segala serba - serbi yang terkait dengan pilgub jateng 2018 [9]

kebutuhan software :

- $\quad$ Android studio 3.1

- Android emulator

- Photoshop

- XML editor

kebutuhan hardware :

- Processor Intel Core i5

- $\quad$ Processor Speed $2.7 \mathrm{GHz}$

- Memory 8 GB

- Grafis Intel Iris Graphics 61001536 MB

b. permasalahan

bagaimana membuat sistem yang mampu berinteraksi dengan pengguna serta mampu memberikan pengalaman dan pengetahuan secara simultan dan tidak terasa membosankan dari segi penyajian, serta bagaimana membuat sistem yang dapat digunakan secara menyeluruh untuk segala umur baik anak -anak remaja dewasa bahakan orang tua. Secara ringkas pemasalahan adalah :

- membuat game yang mampu memberi pengetahuan

- membuat interface yang menarik

- compatible atau mudah digunakan

- $\quad$ sistem mampu bekerja dengan baik

c. tugas (task analysis)

ada beberapa task atau tugas yang akan diimplementasikan kedalam game ini yaitu : 
- $\quad$ sistem pemilihan secara acak / random dari beberapa pertanyaan secara animatif

- sistem menentukan jumlah huruf jawaban yang sesuai

- $\quad$ sistem pengisian jawaban dengan memasukkan huruf

- $\quad$ sistem mampu mencocokan jawaban dank unci jawaban

- $\quad$ sistem mampu melakukan scoring / penilaian hasil jawaban

- $\quad$ sistem mampu memberikan warning untuk jawaban benar dan salah

- sistem memberikan baground suara dan dapat mematikan sesuai kebutuhan user

\subsection{Tahap Desain (Design)}

Tahapan desain adalah proses yang dilakukan mendahului sebelum dilakukan pengembangan sistem. Pada tahapan ini dilakukan dengan penentuan cara atau strategi pembelajaran yang nantinya akan digunakan, dan kemudian model pembelajaran yang akan diterapkan pada aplikasi ini. Sehingga hasil akhir dati tahapan desain ini adalah rancangan atau desain yang mampu menjawab permasalahan dari proses analisis sebelumnya dan memiliki rencana terkait dengan pengalama belajar yang akan diperoleh pengguna aplikasi kedepan[3].

- desain splash screen

- desain home

- desain halaman game

- desain halaman akhir game

- desain halaman informasi

\subsection{Tahap Pengembangan (Development)}

Tahapan pengembangan adalah tahapan untuk mewujudkan secara benar dari tahapan desain yang telah di buat sebelumnya sesuai dengan kaidah - kaidah atau aturan sebuah pencangan perangkat lunak (software). Pada tahapan ini meliputi penentuan dan pemilihan metode pengembangan sistem, serta pemilihan tools dan aplikasi pendukung yang akan digunakan dalam pembuatan sistem atau aplikasi ini nantinya. Hasil dari tahapan ini adalah rancangan aplikasi yang sesuai aturan pengembangan sistem informasi perangakat lunak yang nantinya akan dapat di implenentasikan pada tahapan ADDIE selanjutnya.

\subsection{Tahap Implementasi (Implementation)}

Pada tahapan ini menerapkan semua desain atau perancangan yang telah dibuat pada tahapan sebelumya. Jadi dengan kata lain tahapn ini adalah tahap membuat aplikasi menjadi bentuk aplikasi game yang sesungguhnya, jadi hasil akhir dari tahapan ini adalah sebuah aplikasi game DGBL yang telah siap digunakan namun masih ada tahapan lagi sebelum dapat di gunakan secara umum.

Hasil desain tampilan

- Splash screen

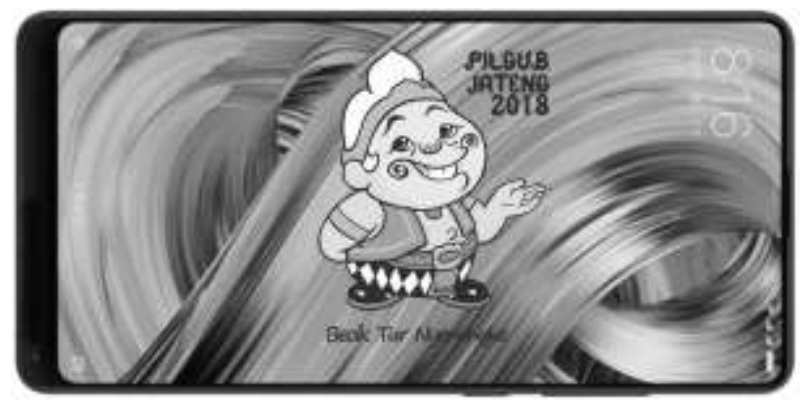

Gambar 2 Spash Screen

TRANSFORMATIKA Vol. 16, No. 1, Juli 2018: $91-97$ 
- Home

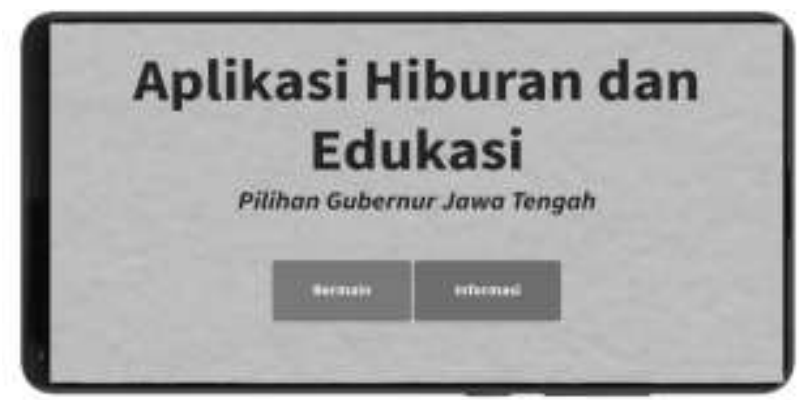

Gambar 3 Gambar Home/ Beranda

- Informasi / media pembelajaran

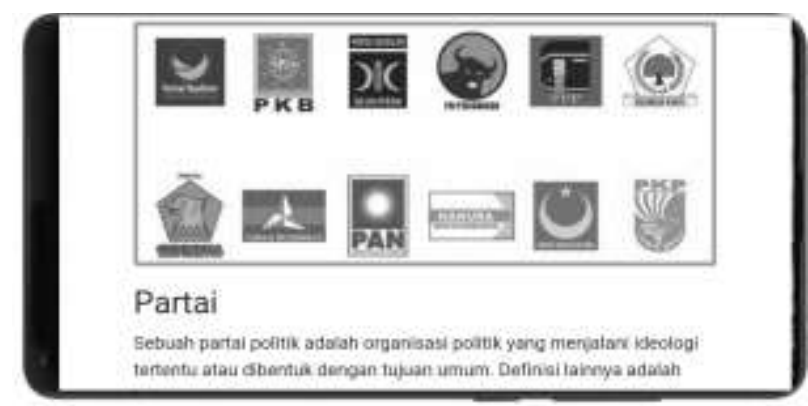

Gambar 4 Gambar halaman informasi

- Petunjuk bermain

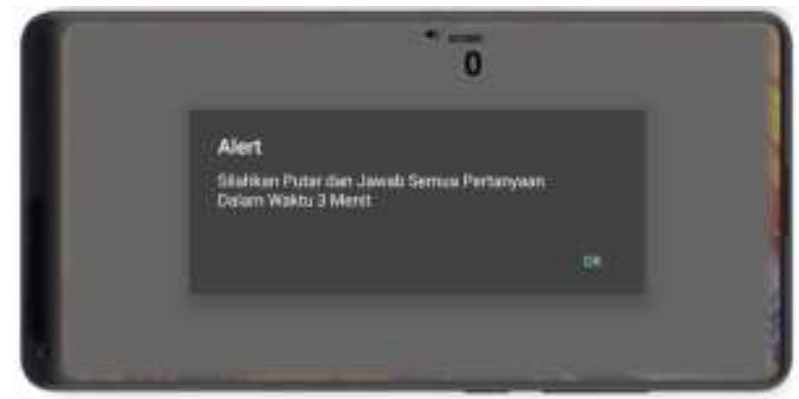

Gambar 5 Gambar petunjuk bermain

- Halaman bermain

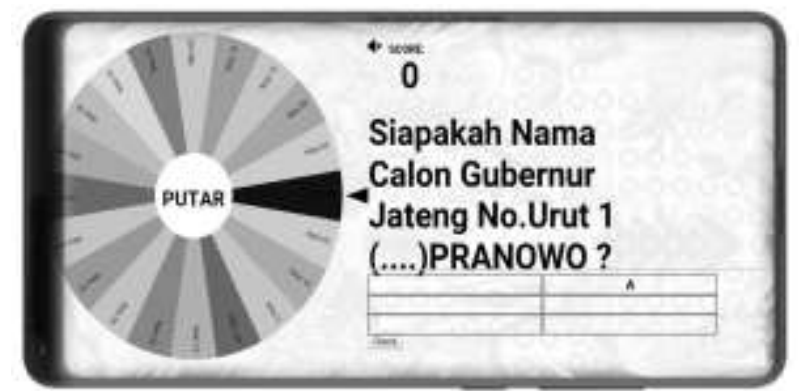

Gambar 6 Gambar Halaman bermain 


\subsection{Tahap Evaluasi (Evaluation)}

Pada tahapan evaluasi game ini dilakukan dengan pengujian black box dimana bebrapa test yang dilakukan adalah pengujian terhadap keterakasesan data informasi, pengambilan soal, dan penjawaban soal serta scoring.

Tabel 1. Pengujian pengambilan data informasi

\begin{tabular}{|l|l|l|l|}
\hline \multicolumn{4}{|c|}{ Kasus dan hasil uji (data normal) } \\
\hline \multicolumn{1}{|c|}{ Data Masukan } & \multicolumn{1}{|c|}{ Hasil Yang diharapkan } & \multicolumn{1}{|c|}{ Hasil pengamatan } & Kesimpulan \\
\hline Klik tombol Informasi & $\begin{array}{l}\text { Menampilkan halaman media } \\
\text { edukasi }\end{array}$ & $\begin{array}{l}\text { Menampilkan halaman media } \\
\text { edukasi }\end{array}$ & Diterima \\
\hline $\begin{array}{l}\text { Klik tombol detail } \\
\text { informasi }\end{array}$ & $\begin{array}{l}\text { Menampilkan halaman detail } \\
\text { informasi }\end{array}$ & $\begin{array}{l}\text { Menampilkan halaman detail } \\
\text { informasi }\end{array}$ & Diterima \\
\hline $\begin{array}{l}\text { Klik tombol halaman } \\
\text { berikut nya (nomor) }\end{array}$ & $\begin{array}{l}\text { Menampilkan halaman } \\
\text { informasi berikut nya }\end{array}$ & $\begin{array}{l}\text { Menampilkan halaman } \\
\text { informasi berikut nya }\end{array}$ & Diterima \\
\hline
\end{tabular}

Tabel 2. Pengujian pengambilan pertanyaan secara acak

\begin{tabular}{|l|l|l|c|}
\hline \multicolumn{5}{|c|}{ Kasus dan hasil uji (data normal) } \\
\hline \multicolumn{1}{|c|}{ Data Masukan } & Hasil Yang diharapkan & \multicolumn{1}{|c|}{ Hasil pengamatan } & Kesimpulan \\
\hline Klik tombol bermain & $\begin{array}{l}\text { Menampilkan panduan cara } \\
\text { bermain }\end{array}$ & $\begin{array}{l}\text { Menampilkan panduan cara } \\
\text { bermain }\end{array}$ & Diterima \\
\hline Klik putar & $\begin{array}{l}\text { Menampilkan animasi } \\
\text { berputar kemudaian berhenti } \\
\text { dan menampilkan } \\
\text { pertanyaan dan kotak lembar } \\
\text { jawab }\end{array}$ & $\begin{array}{l}\text { Menampilkan animasi berputar } \\
\text { kemudaian berhenti dan } \\
\text { menampilkan pertanyaan dan } \\
\text { kotak lembar jawab }\end{array}$ & Diterima \\
\hline Klik putar (lagi) & $\begin{array}{l}\text { Menampilkan animasi } \\
\text { kembali berputar kemudaian } \\
\text { berhenti dan menampilkan } \\
\text { pertanyaan dan kotak lembar } \\
\text { jawab, dengan soal yang } \\
\text { sebelumnya disable }\end{array}$ & $\begin{array}{l}\text { Menampilkan animasi kembali } \\
\text { berputar kemudaian berhenti } \\
\text { dan menampilkan pertanyaan } \\
\text { dan kotak lembar jawab, } \\
\text { dengan soal yang sebelumnya } \\
\text { disable }\end{array}$ & Diterima \\
\hline
\end{tabular}

Tabel 3. Pengujian pengisian jawaban dan scoring

\begin{tabular}{|c|l|l|c|}
\hline \multicolumn{5}{|c|}{ Kasus dan hasil uji (data normal) } \\
\hline \multicolumn{1}{|c|}{ Data Masukan } & Hasil Yang diharapkan & \multicolumn{1}{c|}{ Hasil pengamatan } & Kesimpulan \\
\hline $\begin{array}{l}\text { Mengisi kolom kotak } \\
\text { jawaban dengan benar } \\
\text { kemudian klik tombol } \\
\text { check }\end{array}$ & $\begin{array}{l}\text { Menampilkan peningkatan } \\
\text { score serta memberikan } \\
\text { suara jawaban benar }\end{array}$ & $\begin{array}{l}\text { Menampilkan peningkatan } \\
\text { score serta memberikan suara } \\
\text { jawaban benar }\end{array}$ & Diterima \\
\hline \multicolumn{5}{|c|}{ Kasus dan hasil uji (data tidak normal) } & \\
\hline \multicolumn{5}{|c|}{$\begin{array}{l}\text { Hata Masukan Yang diharapkan } \\
\text { Mengisi kolom kotak } \\
\text { jawaban dengan salah } \\
\text { kemudian klik tombol } \\
\text { check }\end{array}$} & $\begin{array}{l}\text { Menampilkan tidak ada } \\
\text { peningkatan score serta } \\
\text { memberikan suara jawaban } \\
\text { salah }\end{array}$ & $\begin{array}{l}\text { Menampilkan tidak ada } \\
\text { peningkatan score serta } \\
\text { memberikan suara } \\
\text { jawaban salah }\end{array}$ & Diterima \\
\hline
\end{tabular}

\section{Kesimpulan}

Dari penelitian dan pengujian tahapan tersebut diatas maka dapat ditarik sebuah kesimpulan bahawa untuk membuat game yang mampu memberi pengetahuan atentang pemilihan gubernur jateng berbasis android dengan model ADDIE dapat dihasilkan sebuah aplikasi yang mampu memberikan tampilan interface yang menarik serta compatible atau mudah digunakan dan sistem mampu bekerja dengan baik pada sistem operasi android, dimana semua sistem awal seperti pada pengacan soal, animasi putar pada roda score maupun tampilan pengambilan soal sampai dengan pengisian jawaban dapat berproses dengan benar sesuai dengan hasil uji black box

TRANSFORMATIKA Vol. 16, No. 1, Juli 2018: $91-97$ 
yang semua menu atau fitur nya dapat diterima. Saran untuk pengembangan selanjutnya adalah peningkatan fitur atau fasilitas seperti peringkingan berdasarkan jumlah score dan waktu mungkin dapat menjadi pengaya dalam game ini. Serta pengujian terhadap peningkatan pengetahuan mungkin bias menjadi tolok ukur seberapa besar metode game ini memberikan pengalaman pembelajaran dan pengetahuan yang menyenagkan.

\section{References}

[1] S. J. Mcgriff, "Instructional System Design ( ISD ): Using the ADDIE Model," Instr. Syst. Coll. Educ. Penn State Univ., p. 2, 2000.

[2] N. A. . Zin, W. S. Yue, and A. Jaafar, "Digital game-based learning (DGBL) model and development methodology for teaching history," WSEAS Trans. Comput., vol. 8, no. 2, pp. 322-333, 2009.

[3] G. P. Mahardhika, "Digital game based learning dengan model ADDIE untuk pembelajaran doa sehari-hari," Teknoin, vol. 21, no. 2, pp. 115-122, 2015.

[4] M. Flanagan and H. Nissenbaum, "A game design methodology to incorporate social activist themes," Proc. SIGCHI Conf. Hum. factors Comput. Syst. - CHI '07, p. 181, 2007.

[5] S. Aslan, "Digital Educational Games : Methodologies for Development and Software Quality Digital Educational Games : Methodologies for Development and Software Quality," 2016.

[6] G. W. Sasongko and H. Suswanto, "Pengembangan Game Sebagai Media Evaluasi Pembelajaran Pada Mata Pelajaran Perakitan Komputer Kelas X,” pp. 1017-1023, 2017.

[7] C. Usman, K. Candra, and J. T. Informatika, "Rancang Bangun Game Slider Puzzle Berbasis Android Menggunakan Metode Heuristik dengan Teknik Best First Search,” pp. $1-10$.

[8] P. Lankoski, S. Bjork, J. M. Kivikangas, and N. Ravaja, "Game research methods : an overview," Game Res. Methods, no. June, p. 360, 2015.

[9] S. E. Dyta, "Rancang Bangun Aplikasi Game Edukasi Anak untuk Mengenal Bentuk dan Warna Benda," Ranc. Bangun Apl. Game Edukasi Anak Untuk Mengen. Bentuk Dan Warn. Benda, 2013. 